Article

\title{
The Impacts on Illegal Farmland Conversion of Adopting Remote Sensing Technology for Land Inspection in China
}

\section{Taiyang Zhong ${ }^{1{ }^{*},}$ Xianjin Huang ${ }^{1}$, Lifang Ye ${ }^{1}$ and Steffanie Scott ${ }^{2}$}

1 School of Geographic and Oceanographic Sciences, Nanjing University, 163 Xianlin Avenue, Nanjing 210023, China; E-Mails: hxj369@nju.edu.cn (X.H.); sunny.juliana@126.com (L.Y.)

2 Department of Geography and Environmental Management, University of Waterloo, 200 University Ave. West, Waterloo ON N2L 3G1, Canada; E-Mail: sdscott@uwaterloo.ca

* Author to whom correspondence should be addressed; E-Mail: taiyangzhong@gmail.com; Tel.: +86-25-8968-0372; Fax: +86-25-8968-0372.

Received: 29 March 2014; in revised form: 27 June 2014 / Accepted: 3 July 2014 / Published: 17 July 2014

\begin{abstract}
While China's central government has adopted remote sensing technology in land inspection since 2000, little empirical research has been done on its effect. This study aims to measure the effect of satellite imagery-based land inspection (SIBI) on illegal farmland conversion. The data used in this study were collected for the period from 1997 to 2010 at the province-level. The econometrics approach for panel data model was used in this research. The results showed that SIBI has a deterrent effect of approximately 2.42 ha for every increase of $1 \%$ in proportion to the area of prefecture-level regions inspected in a province-level region. The results also indicate land inspections with RS (Remote Sensing) technology saved approximately 11,880 ha farmland from illegal conversion during 2000-2010 with an estimated contribution of reducing illegal farmland conversion by nearly $11 \%$. Furthermore, the governance structure change for land inspection has also contributed to deterring illegal farmland conversion. The deterrent effects due to land inspection by the Supervisor of State Land (SSL) are about 7332 ha during 2008-2010 with an estimated contribution of reducing illegal farmland conversion by nearly $33 \%$. In conclusion, although SIBI has strengthened China's central capacity to uncover illegal farmland conversion and weakened local governments' abilities to hide illegal farmland conversion, it has limited impact on illegal farmland conversion since it is just a technical tool. Improvements in the land inspection governance structure have also helped to deter illegal farmland conversion.
\end{abstract}


Keywords: farmland preservation; illegal land use; deterrent effects; China

\section{Introduction}

Farmland loss and farmland preservation are challenges and hot topics in social and economic development [1-3]. Many studies have addressed the impacts of urbanization, industrialization, economic growth and governance on farmland loss [4-9]. Another threat to farmland preservation in China has been illegal farmland conversion [10-16]. Since the 1978 economic reforms, there has been extensive and persistent unauthorized development carried out without permits [17]. Some studies have indicated that illegal land development is a prevailing phenomenon mainly in rural [11,14] China. From 1999 to 2010, China's farmland loss amounted to 12.98 million ha [18-20]. It was reported that there were 298,400 ha of farmland converted illegally over this period [21-32], equating to about $10 \%$ of total farmland converted to non-agricultural use. Therefore, it is important for farmland preservation to curb illegal farmland. Previous studies regarding China's illegal land use have focused on the causes of illegal farmland conversion in China and placed emphasis on the role of individuals, local governments and the land tenure system [15,33-39]. Beyond analysis of the driving force, research has largely neglected issues of improving relevant laws and regulation and their enforcement, as an element of deterrence.

Enforcement of policies and laws is important to curb illegal arable land conversion [35]. Different countries have developed many tools to preserve farmland. Market-based approaches have been commonly used in North America, including tradable development rights, purchase of development rights or conservation easements, taxes and subsidies [40,41]. Land zoning and land use regulation are also used in North America [41]. Some market-based tools have been developed by local governments in China, for instance, the rewarded land conversion quotas trading scheme [42], which is similar to the purchase of development rights. Comparatively, China's central government has placed emphasis on policy-based land use regulation and zoning to preserve farmland. Whether it is market-based or zoning and land use regulation, monitoring compliance is important for success in policy implementation. For the countries with a private land ownership system, the central issue in farmland preservation is how to involve the farmer in programs to govern farmland conversion. Therefore, it is important to inspect the compliance with agreement of conservation easement and relevant zoning or plan [43,44].

Unlike most Western countries, China has a different land ownership system, with two kinds of ownership: state-owned and collectively owned. Most the farmland in China is collectively owned land where rural households have farmland use rights for a period of 30 years. Despite rural households not being allowed to convert farmland to non-agricultural uses, in practice farmland is frequently illegally converted to non-agricultural use, owing to pressures for industrial, commercial uses and housing $[35,45]$. Moreover, local governments have strong incentives to obtain revenue by converting farmland to non-agricultural uses [13], and local governments are more powerful than the central government in controlling land development [46]. It is at and above the county-level governments' responsibility to curb illegal farmland land conversion. Ironically, local government has also become involved in illegal farmland conversion by illegally approving farmland conversion [47], and has even become the 
biggest violator in terms of amount of illegal farmland conversion $[15,38,48]$, associated with deficient supervision [47]. Therefore, the central issue of implementation of China's farmland preservation policy is how to supervise and compel local governments to fulfill their duty of farmland preservation.

In order to strengthen the implementation of land policies and laws, China's central government has adopted some new technologies in land inspection. Land inspection in this study refers to central government inspections on land users' compliance with, and local governmental enforcement of, land laws and regulations. This inspection is carried out by the Ministry of Land and Resources (MLR). To preserve its relatively scarce farmland, China made significant changes to its institutional arrangements regarding farmland preservation in the late 1990s. Illegal farmland conversion was included in the revised Criminal Law in 1997. Furthermore, China comprehensively revised its Land Administration Law (LAL) and Regulation on Implementation of the LAL in 1998, placing more emphasis on farmland protection. The revised LAL concentrated the administrative power to permit farmland conversion on central and provincial governments. Permits for farmland conversion are subject to the general land use plan and the annual quotas of land use, which are governed through a top-down administration systems. These conversions that constitute violations of land administration laws and regulations include the conversion of farmland to non-agricultural use without permission, issuing illegal permits, and non-conformance to the general land use plan. Detected non-compliance is expected to be punished. Penalties for violation depend on the amount and planned use of the illegally converted farmland, and may include fines, demolishing buildings, confiscating buildings, and criminal penalties [49]. Moreover, the illegal user will likely be required to return the converted farmland to its original state [49].

Land administrative agencies at and above the county level are the major governmental agency responsible for the implementation of laws and regulations regarding farmland preservation. However, local government can receive fiscal revenue by converting farmland to nonagricultural use [50]. This situation has made local governments reluctant to strictly enforce those laws and regulations. Due to huge profits for local government in land leasing or granting [47,51,52], local governments are motivated to develop land, and illegal farmland conversion is one of their options [36]. Such a situation has created a dilemma for the central government, as it has to rely on local governments that are also potential violators to enforce the laws and regulations. Therefore, it is important for the central government to improve the capacity of monitoring compliance as well as supervising local governments' enforcement of laws and regulations regarding farmland protection.

For this reason, the MLR formally implemented the project of land use monitoring based on remote sensing data in 1999, aiming to monitor the land use change in 66 cities with populations of more than half a million [53]. The results of the land use monitoring based on remote sensing data were used by the MLR to check the legitimacy of land use change of the 66 cities between October 1998 and October 1999 [54]. These inspections have been called satellite-image-based inspection (SIBI). The SIBI has been carried out annually since 2000 with the exception of 2003 and 2004. Compared with traditional land inspection, SIBI has the obvious advantage of reducing the central government's dependence on local authorities for obtaining information regarding farmland conversion. SIBI has uncovered more illegal cases of farmland conversion than the traditional method [53]. Therefore, the MLR has made an effort to increase the coverage of SIBI to 86 cities in 2008, and to 172 cities in 2009. Since 2010, SIBI has covered all the county-level jurisdictions in mainland China with 
155 regions directly inspected by the MLR. By 2011, the inspection included not only land use but also mineral development.

Although China's central government formally launched land inspections with remote sensing data (RS) in 2000 and these inspections have covered the whole of mainland China since 2010, no empirical research has been carried out yet to examine its effectiveness. The purpose of this study is to investigate the effect of adopting RS technology for land inspections on illegal farmland conversion in mainland China. The rest of the paper is organized as follows: the data and methodology are presented, followed by the results, discussions and conclusions.

\section{Data and Methodology}

\subsection{Data Sources}

There are systematic and continuous statistical data regarding illegal farmland conversion since 1999. Illegal activities are divided into five types in official statistical source: illegal purchase, sale and transfer; illegal occupation; illegal authorization; damage of farmland; and others [55]. According to the explanatory notes on statistical indicators in China Land Resources Statistical Almanac, the five kinds of illegal activities regarding farmland all result in or are accompanied by illegal farmland conversion. Therefore, in this study, the number of cases of illegal farmland conversion refers to the number of illegal activities regarding farmland and it is the same for the area of illegal farmland conversion. In consideration of the moment when SIBI was formally implemented, it is reasonable to treat 2000 as the transition year for the technological change in land inspections, when the new technology was adopted and the policy of SIBI came into place.

This study used official statistical data regarding illegal farmland conversion to analyze the effect of technology adoption, namely the impact of SIBI. In consideration of the consistency and availability of the data, the research time span is limited to the period from 1999-2010. Some data regarding population etc. were retrieved or calculated from the data in the China Statistical Yearbook, including population, GDP, indices of GDP and general budgetary revenue [21-32,56,57]. Some data regarding illegal land use were retrieved or calculated from the data in the China Land Resources Almanac, including area of illegal farmland conversion, government's income from state-owned land conveyance and area of the farmland approved for conversion to construction use [58-69]. The data for area of regions inspected by the Supervisor of State Land (SSL) using the method of routine inspection were calculated based on the bulletin from the MLR [70-73]. The information on whether or not a province-level region belongs to a quasi-vertical land administration system was collected by searching the public provincial documents regarding the quasi-vertical land administration system reform. Two province-level regions were not included in the data set of this study due to missing data; these were Qinghai Province and Tibet Autonomous Region.

The area covered by SIBI were counted as follows: the area is equal to the sum of the area of inspected districts for four province-level municipalities, and the area is equal to the sum of the area of inspected prefecture-level regions for the other 25 province-level regions (without Qinghai Province and Tibet Autonomous Region) for the years 1999-2009. Although the 2010 inspection with RS technology was carried out nation-wide, only 155 regions (four province-level municipalities plus 
151 prefecture-level regions) were directly inspected by the MLR, so the area of regions inspected by the MLR with RS technology was calculated based on the 155 regions. The GDP at current prices was adjusted to the GDP at constant prices with the base year of 1999.

\subsection{Methodology}

There are different conclusions about the deterrence of environmental inspections [74]. Some empirical research indicated that inspections reduced non-compliance [75], and some research showed contrary results $[76,77]$. Some studies showed that the probability of detection did influence an individual's decision about violation [78]. The expected utility of violations is negatively related with the probability of being caught and conviction [79]. So, it is expected that a decrease in the number of offences would be seen with an increase in the probability of detection $[79,80]$. Following these thoughts, it is reasonable to hypothesize that there would be a similar effect of SIBI on illegal farmland conversion.

SIBI has used land use change derived from satellite images as reference, and then the legitimacy of those land use changes is judged by checking the documents of the land conversion permit [81]. SIBI placed emphasis on those land use conversions to nonagricultural use, conversions which are viewed as illegal, including conversions without permits and conversions done outside of a permitted area [81]. The MLR provides local land administrative agencies with the data about land use change for a specific period, while the concrete work in SIBI is carried out by local land administrative agencies of the inspected cities or counties [81]. To ensure the credibility of self-inspections completed by land administrative agencies of the inspected cities or counties, the MLR carries out selective examinations of the results obtained by local administrative agencies [81]. Under traditional land inspection, it is difficult for the central government to check local government's self-reported illegal farmland conversion due to lack of first-hand information regarding land use change. Compared with traditional land inspection, SIBI has reduced the central government's dependence on local governments in obtaining information regarding land use change, especially information on illegal farmland conversion [82], which increases the probability of illegal farmland conversion being uncovered or caught. Similarly, it is expected that there will be a higher likelihood of illegal farmland conversion being uncovered in those inspected regions than in regions that are not inspected. It is also expected that the higher the rate of area being inspected for a specific region, the higher the likelihood of catching illegal farmland conversion. Assuming the same probability for all the illegal farmland caught, a higher likelihood of being uncovered will lead to a stronger negative impact on illegal farmland conversion. Such a theoretical expectation was used in this empirical study.

The aim in this paper is to examine the impact of technology adoption in land inspections on the illegal farmland conversion. Let $Y_{i t}$ denote the illegal farmland conversion variable associated with province-level region $i$ in period $t$, and the basic equations estimated are of the form.

$$
Y_{i t}=a+\theta T_{i t}+\beta_{k} X_{i t}^{k}
$$

The first variable $T_{i t}$ is the proportion of inspected and monitored area for the province-level region $i$ in period $t$, which was used as an indicator for the technology change of land inspections. The second group of variables $X_{i t}^{k}$ includes the factors influencing $Y_{i t}$ except $T_{i t} . \theta, \beta_{k}$ are the coefficients of the explanatory variables $T_{i t}$, and $X_{i t}^{k}$, respectively. $a$ is the constant. 
Based on the expected causality mentioned above, the coefficient for $T_{i t}$ is expected to have a negative sign. The crucial question is whether SIBI has saved farmlands from illegal conversion. It can be judged from the estimated coefficients related with $T_{i t}$ : if the estimated coefficients related with $T_{i t}$ are consistent with their expected signs and are statistically significant, it can be concluded that land inspections with RS technology have been effective in saving farmland from illegal conversion.

\subsection{The Explanatory Variables and Model Specification}

In term of the extent of the illegal farmland conversion that is reported to occur in a report year, there are several factors that could influence the conversion. Table 1 gives an overview of the definitions, the expected sign of each independent variable and a description of the dependent variables.

The dependent variable used in the model of deterrent effects is the variable $Y_{i t}$. The $Y_{i t}$ refers to the amount of farmland converted illegally in this study. The first set of explanatory variables listed in Table 1 is the variable denoting the technical adoption in land inspection, and the variable pinspection is used for this purpose. The variable pinspection is the percentage of the area of prefecture-level regions inspected by the MLR with RS technology in a province-level region, and the variable pinspection is expected to have a negative sign.

The second set of explanatory variables listed in Table 1 is the variable representing other institutional changes regarding land inspection. It is expected that there will be relationships between the governance structure and illegal farmland conversion [83]. To preserve farmland, a quasi-vertical management reform of local land administration systems below province level was implemented in 2004, since then, it is required that the directors of local land administration agency be appointed by a higher-level agency of land administration. Furthermore, a new inspection agency named the SSL was established to supervise provincial governments' land use administration in 2006 [84]. The major kinds of inspection carried out by the Supervisor of State Land (SSL) include routine or regular supervision, discretionary or special supervision and checking up on permits for agricultural land conversion and expropriation. The routine inspection is a kind of comprehensive inspection on the target region's land use and administration. The discretionary inspection is an inspection for a specific aspect of land use and administration. Two variables are used to denote these changes mentioned above, namely the variable proutine and wvertical. The variable proutine is the percentage of the area of county-level regions inspected by the SSL with routine supervision in a province-level region. The variable wvertical denotes whether a province-level region belongs to a quasi-vertical land administration system and is a dummy variable, whose value takes " 1 " for quasi-vertical land administration system in place and " 0 " otherwise. It is also expected to have a negative sign.

The third set of explanatory variables listed in Table 1 are about a region's characteristics and some other factors that possibly influence illegal farmland conversion, including: plandfinance, sapproval, rgrowth, pergdp, pergdp2, and population. The study uses the variable plandfinance to denote the fiscal dependence on state-owned land leasing or conveyance. It is expected to have a positive sign for the variable plandfinance. It is expected that there will be less illegal farmland conversion for the regions with higher quotas of farmland conversion. While there is no public information about the quotas of farmland conversion, the area of farmland actually approved to conversion by government is available. The variable sapproval was used to measure the quota of farmland conversion allocated by 
central government, which is the area of the farmland approved for conversion to construction use. The hope is to have a negative sign for the variable sapproval. Some studies showed close relationships between illegal land use and economic development [85,86], and the variable rgrowth was used to represent the economic growth rate, which is expected to have positive signs. Illegal land use is possibly relevant with the stage of a region's economic development. The variable pergdp was included in the explanatory variables for this consideration, and it is per capita GDP at constant prices. Some studies confirmed the existence of inverted U-shaped relationships between economic growth and farmland conversion in China [87], so the quadratic term of per capita GDP was also included. Population growth and urbanization have been viewed as a major driving force of farmland land conversion [87-90], and the variable population, whose value is the total population at province level region, was used to analyze its impact on illegal farmland conversion.

Table 1. Variable definitions and expected signs for explanatory variables and dependent variable used in the model of deterrent effects.

\begin{tabular}{|c|c|c|c|}
\hline Set & $\begin{array}{c}\text { Explanatory } \\
\text { variable }\end{array}$ & Variable definitions & Expected Signs \\
\hline $\begin{array}{c}\text { Dependent } \\
\text { variables }\end{array}$ & $Y$ & The amount of farmland illegally converted & \\
\hline$T_{i t}$ & pinspection & $\begin{array}{l}\text { The proportion of the area of prefecture-level regions } \\
\text { inspected by the Ministry of Land \& Resources with RS } \\
\text { technology in a province-level region (\%) }\end{array}$ & - \\
\hline \multirow[t]{2}{*}{$S_{i t}$} & proutine & $\begin{array}{l}\text { The proportion of the area of county-level regions inspected } \\
\text { by the Supervisor of State Land with routine inspection or } \\
\text { supervision in a province-level region (\%) }\end{array}$ & - \\
\hline & wvertical & $\begin{array}{l}\text { Dummy variable for whether a province-level region } \\
\text { belongs to quasi-vertical land administration system, } \\
\text { wvertical = } 1 \text { for quasi-vertical land administration } \\
\text { system in place, and wertical }=0 \text { for otherwise }\end{array}$ & - \\
\hline \multirow[t]{6}{*}{$X_{i t}$} & plandfinance & $\begin{array}{l}\text { Ratio of government's income from state-owned land } \\
\text { conveyance in a province-level region to the general } \\
\text { budgetary revenue in a province-level region }(\%)\end{array}$ & + \\
\hline & sapproval & $\begin{array}{l}\text { Area of the farmland approved for conversion to } \\
\text { construction use (ha) }\end{array}$ & - \\
\hline & rgrowth & The rate of economic growth $(\%)$ & + \\
\hline & pergdp & $\begin{array}{l}\text { GDP per capita at constant prices }\left(10^{4} \text { Yuan/person }\right) \\
\text { at province level }\end{array}$ & + \\
\hline & pergdp2 & Quadratic term of pergdp & - \\
\hline & population & The total population at province level region $\left(10^{4}\right.$ person $)$ & + \\
\hline
\end{tabular}

The descriptive statistics of variables used in this study are presented in Table 2, and Figure 1 presents a description for the changes in most variables across provinces. The first column of Table 2 presents descriptive statistics of dependent variables and the second column presents descriptive statistics of explanatory variables. As it shows, there has been a big disparity in the amount of illegal farmland conversion across provinces over time, and the average number of hectares converted 
illegally was 482 ha in a provincial-level region per record period with a standard deviation 1.50 times the mean. The proportion of the area inspected by SISI shows an uneven distribution, with an average of $18.21 \%$ and a standard deviation of 26.29. Comparatively, the proportion of the area inspected by the Supervisor of State Land shows a more uneven distribution with a standard deviation of 6.17, about three times the mean. The variable of plandfinance has a relatively small standard deviation, which suggests a less uneven distribution for the ratio of government's income from state-owned land conveyance in a province-level region to the general budgetary revenue in a province-level region. This is also indicated by the fact that most local governments have a heavy dependence on the fiscal revenue from public land leasing. Similarly, the standard deviation of the variable of sapproval also indicates less uneven distribution, at about 0.88 times mean. There is relatively even distribution for economic growth rate, and the standard deviation of the variable of rgrowth is 0.22 times the mean. In contrast, the variable of pergdp has a less even distribution, with a standard deviation of 0.69 times the mean.

Table 2. Descriptive statistics of variables used in the study.

\begin{tabular}{lccccc}
\hline Variable & $\begin{array}{c}\text { Number of } \\
\text { observations }\end{array}$ & Minimum & Maximum & Mean & Std. Deviation \\
\hline$Y$ & 348 & 0.00 & 5561.24 & 481.94 & 725.92 \\
pinspection & 348 & 0.00 & 100.00 & 18.21 & 26.29 \\
proutine & 348 & 0.00 & 54.65 & 1.89 & 6.17 \\
wvertical & 348 & 0.00 & 1.00 & 0.51 & 0.50 \\
plandfinance & 348 & 0.35 & 170.47 & 33.65 & 28.77 \\
sapproval & 348 & 23.15 & $36,359.94$ & $5,128.24$ & $4,519.98$ \\
rgrowth & 348 & 5.10 & 23.80 & 11.69 & 2.59 \\
pergdp & 348 & 0.25 & 5.69 & 1.40 & 0.97 \\
pergdp2 & 348 & 0.06 & 32.38 & 2.89 & 4.49 \\
population & 348 & 543.00 & $10,441.00$ & $4,416.83$ & $2,547.60$ \\
\hline
\end{tabular}

Given the above discussion on the basic model and the choice of explanatory variables, the following specification was considered for the equation of deterrent effects:

$$
\begin{aligned}
& Y_{i t}=a_{1}+\theta_{1} \text { pinspection }_{i t}+\theta_{2} \text { pinspection }_{i t-1}+\varphi_{1} \text { proutine }_{i t}+\varphi_{2} \text { proutine }_{i t-1} \\
& +\varphi_{3} \text { wvertical }_{i t}+\beta_{1} \text { plandfinance }_{i t}+\beta_{2} \text { sapproval }_{i t}+\beta_{3} \text { rgrowth }_{i t}+\beta_{4} \text { pergdp } \\
& +\beta_{5} \text { pergdp }_{i t}+\beta_{6} \text { population }_{i t}+u_{i t}
\end{aligned}
$$

where the variable pinspection $_{i t-1}$ and proutine $_{i t-1}$ are the one year lagged term of the variable pinspection $_{i t}$ and proutine $_{i t}$ respectively, which are expected to have negative coefficients. $u_{i t}$ is the error term. $i$ denotes region and $t$ denotes the period. As the variable wvertical is a dummy variable, the equation did not include its lagged term.

The pooled regression, random-effects estimator (RE model) and fixed-effects estimator (FE model) were used to estimate the coefficients of equation. The Hausman test was used for the decision of model choice between RE model and FE model. The relevant tests for models were made and the details on this are given in the results section. 
Figure 1. Variables' mean across provinces during 1999-2010. (a) Farmland converted illegally. (b) Percentage of area inspected by SIBI. (c) Percentage of area inspected by SSL. (d) Ratio of government's land conveyance income to the general budgetary revenue. (e) Population. (f) Farmland permitted to conversion. (g) Rate of GDP growth. (h) GDP per capita.
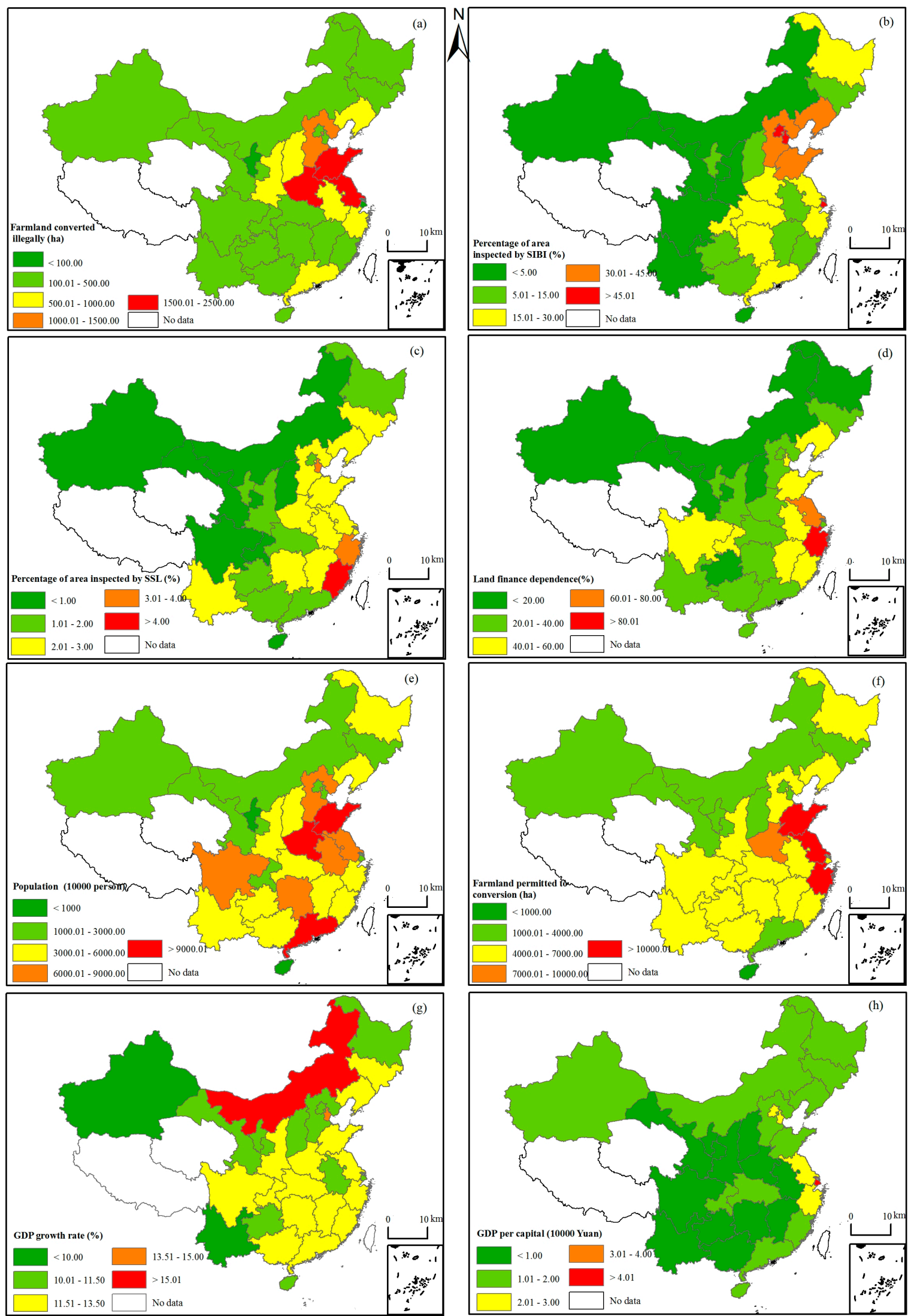


\section{Results and Discussion}

\subsection{Results}

The coefficients for the deterrent effects in Equation (2) were estimated by fixed-effects model. The $\mathrm{F}$ value for the test of fixed-effects is 5.19 and its corresponding $p$-value is 0.00 , which suggests the null hypothesis is rejected and the fixed-effect model is favored. The random-effects model was also estimated. The Breusch-Pagan Lagrangian multiplier test was used to test for random effects where the chi-square is equal to 91.20 and its $p$-value is 0.00 , which suggest that the random-effects model is favored rather than pooled regression. The Hausman test was used to determine whether to have a random-effects model or a fixed-effects model, and the chi-square and its $p$-value in the Hausman test are 64.69 and 0.00, respectively, which suggested that a fixed effect model is better than its random counterpart. The F-value for time-fixed effects is 1.62 and its $p$-value is 0.10 , but all the coefficients of time dummy are not significant, therefore time-fixed effects are not considered. The serial correlation is another problem, and the Wooldridge test [91] for autocorrelation in panel data was made using the STATA's command xtserial [92]. The F-value of the Wooldridge test for autocorrelation in panel data is equal to 1.95 and its $p$-value is 0.17 , which means no serial correlation. Pesaran's CD test was used for cross-sectional dependence with STATA's command of xtcsd [93], and its value and corresponding $p$-value are 4.68 and 0.00 , respectively, which suggested a strong rejection of the null hypothesis of no cross-sectional dependence. The command of xttest 3 was used for the Modified Wald test for groupwise heteroskedasticity [94], the chi-square is $17,009.29$ and its $p$-value is 0.00 , which means having groupwise heteroskedasticity. If cross-sectional dependence is present, Driscoll and Kraay standard errors is suggested for use [95]. In consideration of the groupwise heteroskedasticity, cross-sectional dependence and no serial correlation, the xtscc command in STATA [95] with the options of "fe $\operatorname{lag}(0)$ " was used to correct the error structure of a model for the fixed effect model, whose result was shown as the Model I of Table 3. The estimated coefficients of the variables pinspection ${ }_{i t}$ and proutine $_{i t}$ are consistent with expectation but not statistically significant. However, their one year lagged term pinspection $_{i t-1}$ and proutine $_{i t-1}$ are consistent with their expected signs and are statistically significant. Therefore, another equation excluding the variables pinspection $_{i t}$ and proutine $_{i t}$ was also estimated. The relevant test suggested that a fixed effect model is better. Moreover, the corresponding test mentioned above showed that there existed groupwise heteroskedasticity and cross-sectional dependence, and the xtscc command in STATA was used, whose results are presented in the Model II of Table 3. The two estimated models mentioned above for deterrent effects are shown in Table 3.

The estimated equations perform satisfactorily in terms of goodness of fit. The estimated equations suggested that the amount of illegal farmland is influenced by factors such as technical improvement in land inspection and the changes of governance structure regarding land inspection, economic growth, population and so on. The estimated coefficients for the variable plandfinance are significantly positive at $5 \%$ and its symbols are consistent with the expectation. The value of coefficients for the variable plandfinance in the Model I are 2.88, with its counterpart in Model II being slightly higher, this indicates that for a given province-level region, every increase of 1 percent across time in the variable plandfinance would lead to about 2.88 ha increase of the amount of illegal farmland conversion. In the current policy environment, China's local governments have incentive to maximize 
extra-budgetary revenue by land leasing [96]. There have been some studies indicating that local governments take land from farmers illegally or legally to get local fiscal revenue [96-98]. So, it is not surprising that the variable plandfinance has a positive coefficient, which means more illegal farmland conversion associated with higher dependence on "land finance". The estimated coefficients for the variable sapproval are consistent with the expectation but not significant, which suggests that there the is no correlation between illegal farmland conversion and the amount of farmland permitted to conversion; an increase in farmland conversion permits does not reduce illegal farmland conversion. The annual quotas of farmland conversion are allocated to province-level governments by the MLR, and handed down to local governments through the land administration system. Total annual quota is split into two parts, namely a normal quota and a so-called "flexible quota". The flexible quota is reserved by the MLR and usually allocated to provincial governments at the end of year. Therefore, there is no strong connection between the amount of farmland illegally converted and the quota of farmland conversion.

Table 3. Estimated results of model for deterrent effects.

\begin{tabular}{|c|c|c|c|c|c|c|c|c|}
\hline \multirow{3}{*}{$\begin{array}{c}\text { Explanatory } \\
\text { variable }\end{array}$} & \multicolumn{4}{|c|}{ Model I } & \multicolumn{4}{|c|}{ Model II } \\
\hline & \multicolumn{4}{|c|}{ Drisc/Kraay } & \multicolumn{4}{|c|}{ Drisc/Kraay } \\
\hline & Coefficient & $\begin{array}{c}\text { Standard } \\
\text { Error }\end{array}$ & $\mathbf{t}$ & $p$-value & Coefficient & $\begin{array}{c}\text { Standard } \\
\text { Error }\end{array}$ & $\mathbf{t}$ & $p$-value \\
\hline pinspection $_{i t}$ & -1.92 & 1.77 & -1.08 & 0.29 & & & & \\
\hline pinspection $_{i t-1}$ & -2.42 & 1.18 & -2.04 & 0.05 & -3.04 & 1.06 & -2.87 & 0.01 \\
\hline proutine $_{i t}$ & -4.38 & 3.34 & -1.31 & 0.20 & & & & \\
\hline proutine $_{i t-1}$ & -40.59 & 20.51 & -1.98 & 0.06 & -46.07 & 19.80 & -2.33 & 0.03 \\
\hline wvertical $_{i t}$ & -65.03 & 84.78 & -0.77 & 0.45 & -54.17 & 88.41 & -0.61 & 0.55 \\
\hline plandfinance $_{i t}$ & 2.88 & 1.38 & 2.09 & 0.05 & 3.14 & 1.29 & 2.43 & 0.02 \\
\hline sapproval $_{i t}$ & $-7.18 \times 10^{-4}$ & 0.01 & -0.05 & 0.96 & $-1.41 \times 10^{-4}$ & 0.01 & -0.01 & 0.99 \\
\hline rgrowth $_{i t}$ & 64.54 & 15.56 & 4.15 & 0.00 & 67.71 & 17.76 & 3.81 & 0.00 \\
\hline $\operatorname{pergdp}_{i t}$ & 190.10 & 176.18 & 1.08 & 0.29 & 106.76 & 196.96 & 0.54 & 0.59 \\
\hline $\operatorname{pergdp}_{i t}$ & -18.89 & 23.99 & -0.79 & 0.44 & -15.74 & 25.99 & -0.61 & 0.55 \\
\hline population $_{i t}$ & 0.29 & 0.12 & 2.48 & 0.02 & 0.29 & 0.12 & 2.44 & 0.02 \\
\hline Constant & -1.92 & 1.77 & -1.08 & 0.29 & & & & \\
\hline $\mathrm{N}$ of obs & 348 & & & & 348 & & & \\
\hline $\mathrm{N}$ of groups & 29 & & & & 29 & & & \\
\hline $\mathrm{F}$ & 509.47 & & & & 43.66 & & & \\
\hline $\begin{array}{c}p \text {-value } \\
\text { (F-statistic) }\end{array}$ & 0.00 & & & & 0.00 & & & \\
\hline within $\mathrm{R}^{2}$ & 0.20 & & & & 0.19 & & & \\
\hline
\end{tabular}

Based on the estimated equations, economic growth has a significant positive influence on the amount of illegal farmland conversion reported and happening in a report year. The coefficient for the independent variable of rgrowth is of statistical significance at a 1 percent level both in Model I and Model II and is consistent with expectation. The coefficient of rgrowth is 64.54 in Model I, which suggests that for every increase of 1 percent, the amount of illegal farmland conversion increases about 65 ha. The coefficients for the independent variables pergdp and pergdp 2 are consistent with the 
expectation but are of no statistical significance in both Model I and Model II. A positive coefficient for the independent variable of rgrowth suggested that China's economic growth has been coupled with consumption of farmland. Actually, a study indicated that China's urban land expands by $3 \%$ as the corresponding economy grows by 10\% [99]. Annual growth of local GDP has been used as one of the principal indicators to evaluate local leadership [96]. As public land sale has a positive effect on China's local economic growth [100], and land supply could be a constraint on economic growth [101], illegal farmland conversion may be a preferred option of local government. Furthermore, rural non-agricultural economy such as collective industrial development has also contributed to illegal farmland conversion $[35,45,102]$. Despite argument for the establishment of a special policy to transfer illegal land to legal land [103], it is more reasonable to induce intensive use of non-agricultural land and strictly handle illegal farmland conversion in consideration of China's demand for food security.

Population is another factor influencing the amount of illegal farmland conversion reported and happening in a report year. The coefficients for the explanatory variables are consistent with the expectation and are of statistical significance at 5\% both in Model I and Model II. The value for the coefficient of the variable population in Model I is 0.29 , with its counterpart in Model II being slightly smaller, indicating that for a given province-level region, as the variable population increases across time by 10,000 persons, the amount of illegal farmland conversion reported and happening in a report year increases by 0.29 ha. Similar to the effect of economic growth on illegal farmland conversion, an increase in population means an increase in demand for land derived from accommodation demand, and such demand may be met by illegal land development over farmland [45,102]. However, urban sprawl suggests illegal farmland conversion is irrational, and the phenomenon of decoupling between population and farmland occupation has also been observed [104]. Therefore, attention should be given to developing policies of intensive land use that encourage accommodating larger populations and non-agricultural activities [105]. Illegal farmland conversion needs to be curbed to reduce irrational sprawl.

\subsection{Discussion}

\subsubsection{The Impact of Technology Adoption for Land Inspection}

The data listed in Table 4 provide some information on SIBI and illegal farmland land conversion. This information was attained by aggregating provincial level data into the data of country-level and juxtaposing the proportion of inspected regions with SIBI and the amount of farmland illegally converted. The data listed in Table 4 showed a negative correlation between SIBI and illegal farmland land conversion, namely the total amount of farmland illegally converted decreased with the increase of the coverage of SIBI.

Based on the estimated equations of deterrent effects of land inspection (summarized as Table 3), the technological changes in land inspections did reduce illegal farmland conversion. The deterrent effect of inspection is divided into two different types by some research, namely specific deterrent effect and general deterrent effect [74]. The former refers to the impact of inspections on the monitored firm's subsequent environmental performance, and the latter refers to the influence of inspections on the performance of a large number of firms not limited to the monitored firms, which is usually measured at an aggregate level [74]. The concern of this paper is to investigate the general deterrent 
effect of SIBI illegal farmland conversion. The estimated results showed that SIBI has lagged in general deterrent effect. Table 3 showed that the coefficient of the variable pinspection ${ }_{i t}$ is consistent with expectation but is not statistically significant, which means the land inspections using RS technology have no significant influence on the illegal farmland conversion in the same period. However, this does not mean that there are no significant impacts of SIBI on illegal farmland conversion, and the deterrent effect is indicated by the one year lag in the variable pinspection ${ }_{i t}$, namely the variable pinspection $_{i t-1}$, whose estimated coefficients are consistent with expectation and are of statistical significance in both Model I and Model II. The coefficients of statistical significance indicate the lagged effects of SIBI, which means that a SIBI significantly reduces the illegal farmland conversion in its following years. The value of the variable of pinspection $_{i t-1}$ in Model I is -2.42 , with its counterpart in Model II being slightly higher, suggesting that SIBI reduces the amount of farmland illegally converted at approximately 2.42 ha for every increase of 1 percent in proportion of the area covered by SIBI in a province-level region. Besides general deterrent effect, some reports also indicated the specific deterrent effect of SIBI. Two bulletins from the SSL showed that the amount of farmland illegally converted in those cities inspected using satellite-images were reduced by $19.60 \%$ and $51.57 \%$ for 2008 and 2009, respectively [72,73]. This indicates that improvement in the technology of land inspection did deter some potential violation.

Table 4. The proportion of inspected regions covered by SIBI and farmland converted illegally.

\begin{tabular}{ccc}
\hline Year & $\begin{array}{c}\text { The proportion of the inspected } \\
\text { prefecture-level regions (\%) }\end{array}$ & $\begin{array}{c}\text { The amount of farmland } \\
\text { illegally converted (ha) }\end{array}$ \\
\hline 1999 & 0.00 & $5,481.78$ \\
2000 & 7.85 & $5,843.22$ \\
2001 & 7.15 & $8,050.10$ \\
2002 & 6.44 & $9,586.57$ \\
2003 & 0.00 & $17,770.60$ \\
2004 & 0.00 & $19,262.60$ \\
2005 & 1.83 & $13,805.37$ \\
2006 & 1.63 & $25,504.55$ \\
2007 & 11.88 & $26,744.46$ \\
2008 & 10.80 & $12,906.37$ \\
2009 & 21.89 & $12,792.83$ \\
2010 & $100.00\left(22.68^{\mathrm{b}}+77.32^{\mathrm{c}}\right)$ & $10,922.65$ \\
\hline
\end{tabular}

Note: ${ }^{a}$ the proportion is equal to the proportion of the area of prefecture-level regions inspected with RS technology in total land area of mainland China; ${ }^{b}$ it is the proportion of the area of prefecture-level regions directly inspected by the Ministry of Land and Resources with RS technology in the total land area of mainland China; ${ }^{c}$ it is the proportion of the area of prefecture-level regions inspected by departments of land and resources at province-level. Source: The total amount of farmland illegally converted was calculated from the dada in the China Land \& Resources Almanac during 2001-2010 [58-69]. The proportion was calculated from the information in public government documents issued by the MLR.

SIBI has enhanced the central government's capacity to uncover illegal farmland conversion and contribute to deterring illegal farmland conversion. SIBI has the capacity to uncover some illegal 
farmland conversions at a larger scale than the traditional and conventional means of land inspection, and it is more convenient and timely. Unlike in the US and Canada, where state or provincial and local governments are left to develop their own farmland protection policy [106,107], China has a national policy to preserve farmland. Furthermore, China has a top-down system of land use planning, through which the quota of farmland preservation is allocated [89]. China's local governments' planning goals for farmland preservation are not allowed to be lower than the next-higher level government's plan. However, China's central government's interest in farmland preservation has been challenged by local governments. As in some Western countries, farmland preservation has been faced with a lack of local governments' support and cooperation [108]. China's local governments have a strong motivation to convert farmland to non-agricultural uses [15]. There has been notable differences in local government's reactions to conflicts in farmland preservation compared to Western countries such as the US and Canada. Due to conflicting interests, local governments in the US and Canada are probably reluctant to cooperate in planning for farmland preservation [40,108]. While Chinese local governments adhere to the central government's planning goals and guidelines in farmland preservation, local governments have not seriously implemented their general land use plan [44]. Besides frequently amending the local general land use plan, such as has also been observed in Canada [108]. Chinese local governments even directly violate laws or regulations to convert farmland to non-agricultural use. A study indicated that local governments used illegal land conversion to disregard or circumvent the central government's land administration policy [15,109]. Therefore, it is important for China's central government to obtain exact information on farmland conversion, and satellite image-based land use change monitoring enables the central government to achieve this.

China's central government formally launched satellite image-based land use change monitoring in 1999 [53], the results of which were used to implement SIBI in 2000 [81]. Since 1999, satellite image-based land use change monitoring has been carried out annually. Similar to the Farmland Mapping and Monitoring Program (FMMP) in California, USA, which biennially tracks changes in agricultural and other land uses [110], China's satellite-image based land use monitoring has been implemented annually and was enlarged to cover the whole of mainland China in 2009. As one study indicated, periodic monitoring and inspection is important for compliance and violation reduction [43]. SIBI (satellite image-based inspection) initiated by China's central government pushed local governments to actively react to and respect the central government's laws and policies regarding farmland preservation. For land use change detection, the larger the area, the higher the likelihood of being detected. In fact, many concealed cases of farmland conversion were exposed by land use monitoring based satellite images in 1996 [53], and higher resolution satellite images were used in 1999 [53], with the results being used by the first SIBI. Therefore, the implementation of SIBI has contributed to weakening local governments' abilities to hide illegal farmland conversion [12,82]. Moreover, SIBI fostered the local land administration agencies' capabilities to detect illegal farmland and it also contributed to alleviating the pressure on local land administration agencies' to handle illegal farmland conversion.

Since local land administration agencies are under local government administrative control, it is difficult for these agencies to handle illegal farmland conversion. SIBI has supported local land administration agencies in handling such cases since SIBI could be viewed as intervention and pressure from the central government. So, while SIBI purportedly has been used by the central government and its land administration authority to detect illegal land conversion, in fact it has been 
used by the central government to compel local government to care about the central government's position regarding farmland preservation.

There are significant differences between traditional land inspections by the central government and SIBI. SIBI has changed the rules of the game on handling illegal farmland conversion: local government has to prove the legality of farmland conversion suspected to be illegal by the central government, which pushes local governments to fulfill their responsibility of inspecting farmland use and seriously curbing illegal farmland conversion. The establishment of a Supervisor of State Land has actually intensified the inspection and supervision from the central government, and its inspections have been associated with a continuous decrease in the amount of detected illegal farmland conversion since 2007.

The top down administrative system and improved accountability system have helped SIBI deter illegal farmland conversion. Although local governments are interested in land development and farmland conversion, and prioritize economic growth over food security, China's central government has strong control over the promotion of local government officials. This makes it impossible for local governments to completely ignore the requirement of farmland protection and land inspection carried out by the MLR [111]. Due to the clash of interests between the central and local governments, it is necessary that policies are implemented to hold China's local governments accountable [112]. To this end, China's central government has improved the policy regarding farmland protection and has made local governments more accountable to deter illegal land use. For instance, the Provisional Regulations for Sanction on Violating Land Administration Decree which was issued in 2000 and revised in 2008 [113], has a quantitative limit regarding illegal farmland conversion and places sanctions on local government's shirking of their duty to deter illegal land use. Furthermore, the MLR has gradually standardized the implementation of SIBI. The MLR issued Case-filing Criteria for the Investigation and Handling of Land-related Violations in 2005 [114] and Specifications for Land and Mineral Inspection Based on Satellite Image in 2010 [115].

However, SIBI still has a limited effect on deterring illegal farmland conversion. It did not offset the effect caused by those factors that increased illegal farmland conversion. Hence, the total amount of farmland converted illegally experienced a continuous increases from 2000-2004 and from 2005-2007, despite the implementation of SIBI (Table 4). These findings suggested that technical improvement in land inspections is not a panacea for curbing illegal farmland conversion since its effect depends on the sanctions for non-compliance. In practice, local governments are inclined to be lenient on illegal farmland conversion. Although the implementation of SIBI has enabled the central government to obtain more information about illegal farmland conversion, SIBI alone cannot ensure that local governments handle illegal farmland detected by SIBI strictly in accordance with laws and regulations. If there is no effective sanction on violations, SIBI could be a "straw man". Interestingly, the total amount of illegally converted farmland has continuously decreased since 2008 and the pace of illegal farmland conversion has significantly slowed down since 2008. Two changes have occurred that went along with these decreases in illegally converted farmland. First was the significant increase in coverage of SIBI since 2007. The proportion of inspected regions covered by SIBI increased from $1.63 \%-11.88 \%$ during 2006-2007 and increased to $21.89 \%$ in 2009 (Table 4). The other factor was the establishment of a new inspection organization in 2006, namely the SSL (Supervisor of State Land). This newly established supervisory body has increased inspections on local land use and administration, 
especially of provincial and municipal level governments. The latter's impact on illegal farmland conversion will be discussed further below.

\subsubsection{Impact of Changes in Governance Structure Change for Land Inspection}

The establishment of the Supervisor of State Land (SSL) has intensified local governmental efforts to curb illegal farmland conversion. Laws and policies of farmland protection by themselves do not ensure compliance, nor does new technology adoption in land inspection. Comparatively, China's farmland policy has placed emphasis on overseeing rather than supervision. Although China's central government concentrated the administrative power of permitting farmland conversion to central and provincial governments by amending the LAL in 1998, it did not pay much attention to inspection of local governments' permits of farmland conversion until 2006. To strengthen local governmental enforcement of policies regarding land use, China's central government adjusted the structure for governance of the land inspections. China's central government established the SSL in 2006, its principal missions are to inspect local government performance of farmland protection and to enforce land laws and regulations [116]. The establishment of the SSL is one of the central government's policy responses to illegal land conversion [97]. The variable proutine ${ }_{i t}$ was used to measure the impact of changes in the structure of land inspection governance due to the establishment of the Supervisor of State Land. Its estimated coefficient is consistent with expectation but not statistically significant. However, the estimated coefficients for its one year lagged term, namely the variable proutine $_{i t-1}$, are consistent with expectation and are of statistical significance in both Model I and Model II. The coefficients of statistical significance also suggest the lagged effects of land inspection by the SSL. The value of the variable proutine $_{i t-1}$ in Model I is -40.59 , with its counterpart in Model II being slightly higher, which suggests that lagged land inspections by the Supervisor of State Land reduce the illegal farmland conversion by approximately 41 ha for every $1 \%$ increase in proportion of the area of county-level regions inspected by the SSL in a province-level region. This indicated that the inspection and supervision from the newly-established SSL has contributed to reduce illegal farmland conversion.

The Supervisor of State Land is a highly centralized system [97], which includes the office of inspector-general and nine regional bureaus. The Supervisor of State Land is a government organization that the State Council authorized the MLR to set up to oversee or inspect land use administration of provincial governments [84], and it is relatively independent from the MLR. Its personnel quota is 360 persons [84], which is nearly same as that of the MLR. There actually is an internal sector under the MLR, named the Bureau of Inspection of Law Enforcement, that has functions similar to the Supervisor of State Land, and whose administrative ranking is the same as the nine regional offices of the Supervisor of State Land. The Bureau of Inspection of Law Enforcement is MLR's sub-sector responsible for carrying out nation-wide SIBI. Besides cooperating with the Bureau of Inspection of Law Enforcement in the implementation of SIBI, the Supervisor of State Land carries out inspections and assessment of local governments' land use administration, especially local governments' performance in the enforcement of land laws and regulations. It also carries out follow-up assessments on local governments' improvement and rectification in land laws and regulation enforcement, which aims to ensure that the way local governments handle violations meets the criteria of enforcement. Since farmland protection is one of the key concerns of the Supervisor of State Land, 
inspections and supervision from the Supervisor of State Land have pushed local governments to enhance their efforts in handling illegal farmland conversion.

Another change in governance structure regarding land inspection is the reform known as quasi-vertical management reform of the local land administration system below province level, which was launched by China's central government in 2004. The variable wvertical $i t$ was used to catch changes due to this reform. The coefficients of the variable wvertical $_{i t}$ are consistent with the expectation but of no statistical significance, which indicated that this reform didn't reduce the amount of illegal farmland conversion. It is not surprising that there were no deterrent effects for the quasi-vertical management reform of local land administration system below province level. The later was a result of the Chinese central government's compromise with local governments. There were differences in interest between the central government and local governments [43,117]. Local governments have been enthusiastic about land development and have set up a large number of development zones [118]. The local governments have the ability to interpret agricultural land protection mandates from their higher level governments and the central government [119]. This has weakened the effect of the central government's efforts in farmland preservation.

\subsection{Comparing Effects of Technology Adoption and Supervision by Supervisor of State Land}

As both the values of the variables pinspection $_{i t}$ and proutine $_{i t}$ have the unit of percentage, so do their one-year lagged terms, namely, the variables pinspection $_{i t-1}$ and proutine $_{i t-1}$. Given that these variables all refer to the proportions of regions' area inspected, it is appropriate to compare the effects of SIBI and the effects of land inspection by the Supervisor of State Land. The absolute value of the

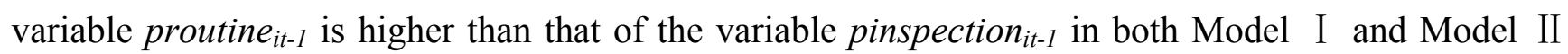
presented in Table 5, which means that for every increase of $1 \%$ of coverage by land inspection across time for a provincial region, the amount of illegal farmland conversion decreases due to land inspection by the Supervisor of State Land more than that due to SIBI. It is approximately 40 ha higher for the marginal deterrent effects of land inspection by SSL than that of SIBI.

The area of farmland saved from illegal conversion due to land inspections can be computed by comparing the predicted amount of farmland illegally converted with and without land inspections. Given the estimated equation for the deterrent effects of land inspection, the deterrent effects of land inspections were calculated, which were shown as Table 5. During 2000 and 2010, the sum of the deterrent effect due to SIBI is 11,880 ha and 14,966 ha, respectively, based on Model I and Model II, and their ratio to the amount of farmland illegally converted during same period are $9.64 \%$ and $12.21 \%$, respectively. In other words, it is estimated that SIBI contributed to reduce illegal farmland conversion by $9.64 \%$ and $12.21 \%$, respectively based on Model I and Model II . During 2008 and 2010, the sum of the deterrent effect due to land inspection by SSL is 7331.83 ha and 8320.01 ha, respectively, and their ratio to the amount of farmland illegally converted during the same period are $31.20 \%$ and $35.41 \%$, which indicated that land inspection by SSL contributed to reduce illegal farmland conversion by $31.20 \%$ and $35.41 \%$, respectively based on Model I and Model II. Roughly, the SIBI and land inspection by SSL have reduced illegally converted farmland by $11 \%$ and $33 \%$, respectively. 
Table 5. The deterrent effects of land inspections.

\begin{tabular}{ccccccccc}
\hline \multirow{2}{*}{ Year } & $\begin{array}{c}\text { Deterrent effects } \\
\text { due to SIBI (ha) }\end{array}$ & \begin{tabular}{c} 
a \\
\cline { 2 - 8 }
\end{tabular} & $\begin{array}{c}\text { Deterrent effects } \\
\text { due to land inspections } \\
\text { by SSL (ha) }\end{array}$ & $\begin{array}{c}\text { Deterrent effects } \\
\text { due to SIBI (\%) }\end{array}$ & \multicolumn{2}{c}{$\begin{array}{c}\text { Deterrent effects } \\
\text { due to land inspections } \\
\text { by SSL (\%) }\end{array}$} \\
\hline 1999 & 0.00 & 0.00 & 0.00 & 0.00 & 0.00 & 0.00 & 0.00 & 0.00 \\
2000 & 0.00 & 0.00 & 0.00 & 0.00 & 0.00 & 0.00 & 0.00 & 0.00 \\
2001 & $1,589.95$ & $2,002.92$ & 0.00 & 0.00 & 19.92 & 25.09 & 0.00 & 0.00 \\
2002 & $1,438.38$ & $1,811.99$ & 0.00 & 0.00 & 15.05 & 18.95 & 0.00 & 0.00 \\
2003 & $1,269.81$ & $1,599.62$ & 0.00 & 0.00 & 7.18 & 9.05 & 0.00 & 0.00 \\
2004 & 0.00 & 0.00 & 0.00 & 0.00 & 0.00 & 0.00 & 0.00 & 0.00 \\
2005 & 0.00 & 0.00 & 0.00 & 0.00 & 0.00 & 0.00 & 0.00 & 0.00 \\
2006 & 656.48 & 826.99 & 0.00 & 0.00 & 2.58 & 3.25 & 0.00 & 0.00 \\
2007 & 391.95 & 493.76 & 0.00 & 0.00 & 1.49 & 1.88 & 0.00 & 0.00 \\
2008 & $1,917.20$ & $2,415.17$ & 0.00 & 0.00 & 14.97 & 18.86 & 0.00 & 0.00 \\
2009 & $1,574.37$ & $1,983.29$ & $1,799.16$ & $2,041.65$ & 12.43 & 15.66 & 14.20 & 16.12 \\
2010 & $3,042.18$ & $3,832.35$ & $5,532.67$ & $6,278.36$ & 28.09 & 35.38 & 51.08 & 57.97 \\
\hline
\end{tabular}

Note: ${ }^{a}$ it is computed based on the estimated coefficients for the equations of deterrent effects and the value of the variables pinspection pit- $1_{1}$ and proutine pit- $_{1}$; ${ }^{\mathrm{b}}$ it is computed as the absolute value of deterrent effects based on Model I or Model II/the total amount of farmland converted illegally.

It is fundamental for any government to ensure compliance with its policies [120]. China's central government has done a good job in developing policies of farmland preservation in recent decades, especially in the systems of planning and farmland conversion permits [111]. The real challenge that China's central government has faced is how to effectively implement those policies at the local level. SIBI has reduced the central government's dependence on local governmental information on land use, especially information on farmland conversion. However, mere improvement in monitoring capacity of the central government has indicated that it is far from enough to prompt local governments to curb illegal farmland conversion. It has been found that China's local governments have the ability to interpret agricultural land protection mandates from the central government and their higher level governments [119], and local governments often manage to bypass and even ignore central government's directives [35]. Therefore, another challenge for China's central government is how to urge local authorities to care about and appropriately respond to farmland protection directives from higher authorities. The Supervisor of State Land has been established for this purpose. Although the Supervisor of State Land participated in the implementation of a nation-wide SIBI which the Bureau of Inspection of Law Enforcement under MLR is responsible for, the Supervisor of State Land has placed emphasis on local government's response to directives from center. For instance, the Supervisor of State Land can check whether local governments fulfill their duties in handling illegal farmland conversion caught through SIBI. Although the Supervisor of State Land has no right to punish officials involved in illegal land use, it has the right to forward illegal land use cases to the Ministry of Supervision [116]. Furthermore, the Supervisor of State Land has the right to request rectification from local government and freeze the approval of agricultural land conversion to non-agricultural use [116]. 
Compared with the Bureau of Inspection of Law Enforcement under MLR, the Supervisor of State Land is a stronger and more powerful watchdog, which has exerted much more pressure upon local governments to curb illegal farmland conversion. Therefore, the inspection from the Supervisor of State Land has a higher marginal effect value than that of SIBI.

\section{Conclusions}

To preserve its scarce farmland, China has improved the system of monitoring and enforcement regarding illegal farmland conversion in recent decades. The empirical results show that adoption of remote sensing technology in land inspection has deterred illegal farmland conversion. The results indicated that the implementation of SIBI reduced illegal farmland conversion by approximately $11 \%$ during 2000 and 2010. There are two key factors to RS technology having a significant deterrent effect. First is its capacity to uncover illegal farmland conversions more conveniently and more quickly than conventional land inspection. Second is China's central government's relatively strong control of the promotion of local government officials.

Despite its deterrent effect, land inspection based on satellite imagery is just a technical tool and its deterrent effect is limited. It is not the first element for slowing the pace of illegal farmland conversion. Comparatively, the changes in the supervision system also contributed to slowing down illegal farmland conversion. The empirical results suggest that supervision from the Supervisor of State Land has also caused deterrence of illegal farmland conversion, reducing illegal farmland conversion by approximately 33\% during 2009 and 2010. However, the quasi-vertical administration reform of local land administration systems below province level has not been a successful reform from the perspective of stemming illegal farmland.

Both the deterrent effect of SIBI and inspection from the Supervisor of State Land indicate that supervision is important for the implementation of farmland preservation policies. Supervision of inspections has contributed to a reduction in farmland loss from the non-permit channel and helped strengthen the control of farmland conversion permits on farmland loss. Besides the improvement of the central government's capacity to obtain information about farmland land conversion, a relatively independent watchdog is also helpful for the central government to push local governments to act for farmland preservation.

\section{Acknowledgments}

This research was supported by the grants from National Natural Science Foundation of China (No. 41271190) and State Scholarship Fund of China (No. 201208320127). The authors would like to acknowledge three anonymous reviewers for their constructive comments. Authors are indebted to Kate Morgan for her language editing.

\section{Author Contributions}

Taiyang Zhong and Xianjin Huang designed this research. Lifang Ye collected the data. Taiyang Zhong and Steffanie Scott analyzed the data and wrote paper. All authors have read and approved the final manuscript. 


\section{Conflicts of Interest}

The authors declare no conflict of interest.

\section{References and Notes}

1. Francis, C.A.; Hansen, T.E.; Fox, A.A.; Hesje, P.J.; Nelson, H.E.; Lawseth, A.E.; English, A. Farmland conversion to non-agricultural uses in the US and Canada: Current impacts and concerns for the future. Int. J. Agric. Sustain. 2012, 10, 8-24.

2. Nelson, A.C. Economic critique of U.S. prime farmland preservation policies: Towards state policies that influence productive, consumptive, and speculative value components of the farmland market to prevent urban sprawl and foster agricultural production in the United States. J. Rural Stud. 1990, 6, 119-142.

3. Bunce, M. Thirty years of farmland preservation in North America: Discourses and ideologies of a movement. J. Rural Stud. 1998, 14, 233-247.

4. Long, H.; Liu, Y.; Wu, X.; Dong, G. Spatio-temporal dynamic patterns of farmland and rural settlements in Su-Xi-Chang region: Implications for building a new countryside in coastal China. Land Use Policy 2009, 26, 322-333.

5. Long, H.; Tang, G.; Li, X.; Heilig, G.K. Socio-economic driving forces of land-use change in Kunshan, the Yangtze River Delta economic area of China. J. Environ. Manag. 2007, 83, 351-364.

6. Seto, K.C.; Kaufmann, R.K. Modeling the drivers of urban land use change in the Pearl River Delta, China: Integrating remote sensing with socioeconomic data. Land Econ. 2003, 79, 106-121.

7. Yeh, A.G.O.; Li, X. Economic development and agricultural land loss in the Pearl River Delta, China. Habitat Int. 1999, 23, 373-390.

8. Zhu, J.; Hu, T. Disordered land-rent competition in China's periurbanization: Case study of Beiqijia Township, Beijing. Environ. Plan. A 2009, 41, 1629-1646.

9. Tan, R.; Qu, F.; Heerink, N.; Mettepenningen, E. Rural to urban land conversion in China-How large is the over-conversion and what are its welfare implications? China Econ. Rev. 2011, 22, $474-484$.

10. Cai, Y. Collective Ownership or Cadres' Ownership? The Non-agricultural Use of Farmland in China. China Q. 2003, 175, 662-680.

11. Ho, S.P.S.; Lin, G.C.S. Emerging land markets in rural and urban China: Policies and practices. China Q. 2003, 175, 681-707.

12. Ho, S.P.S.; Lin, G.C.S. Converting land to nonagricultural use in China's coastal provinces-evidence from Jiangsu. Mod. China 2004, 30, 81-112.

13. Lichtenberg, E.; Ding, C. Assessing farmland protection policy in China. Land Use Policy 2008, $25,59-68$.

14. Tang, W.-S.; Chung, H. Rural-urban transition in China: Illegal land use and construction. Asia Pac. Viewpoint 2002, 43, 43-62.

15. Lin, G.C.S.; Ho, S.P.S. The state, land system, and land development processes in contemporary China. Ann. Assoc. Am. Geogr. 2005, 95, 411-436. 
16. Song, X.Q.; Ouyang, Z.; Li, Y.S.; Li, F.D. Cultivated land use change in China, 1999-2007: Policy development perspectives. J. Geogr. Sci. 2012, 22, 1061-1078.

17. Li, X.; Lao, C.H.; Liu, Y.L.; Liu, X.P.; Chen, Y.M.; Li, S.Y.; Ai, B.; He, Z.J. Early warning of illegal development for protected areas by integrating cellular automata with neural networks. J. Environ. Manag. 2013, 130, 106-116.

18. MLR (Ministry of Land and Resources). China Land and Resources Statistical Yearbook 2005; MLR: Beijing, China, 2006; pp.14-15, 156-157.

19. MLR (Ministry of Land and Resources). China Land and Resources Statistical Yearbook 2011; Geological Pbulishing House: Beijing, China, 2012; pp.16-17, 87-88, 174-177.

20. MLR (Ministry of Land and Resources). China Bulletin on Land and Resources 2013. Available online: http://www.mlr.gov.cn/zwgk/tjxx/201404/t20140422_1313358.htm (accessed on 5 May 2014). (in Chinese)

21. NBSC (National Bureau of Statistics of China). China Statistical Yearbook 2000; China Statistics Press: Beijing, 2000; pp. 60-63, 96, 272-275. (in Chinese)

22. NBSC (National Bureau of Statistics of China). China Statistical Yearbook 2001; China Statistics Press: Beijing, China, 2001; pp. 56-59, 91, 262-265. (in Chinese)

23. NBSC (National Bureau of Statistics of China). China Statistical Yearbook 2002; China Statistics Press: Beijing, China, 2002; pp. 58-61, 98-99, 275-278. (in Chinese)

24. NBSC (National Bureau of Statistics of China). China Statistical Yearbook 2003; China Statistics Press: Beijing, China, 2003; pp. 63-66, 98, 293-296. (in Chinese)

25. NBSC (National Bureau of Statistics of China). China Statistical Yearbook 2004; China Statistics Press: Beijing, China, 2004; pp. 61-64, 96, 298-301. (in Chinese)

26. NBSC (National Bureau of Statistics of China) China Statistical Yearbook 2005; China Statistics Press: Beijing, China, 2005; pp. 59-62, 94, 279-282. (in Chinese)

27. NBSC (National Bureau of Statistics of China) China Statistical Yearbook 2006; China Statistics Press: Beijing, China, 2006; pp. 63-66, 101, 289-292. (in Chinese)

28. NBSC (National Bureau of Statistics of China) China Statistical Yearbook 2007; China Statistics Press: Beijing, China, 2007; pp. 67-70, 106, 287-290. (in Chinese)

29. NBSC (National Bureau of Statistics of China) China Statistical Yearbook 2008; China Statistics Press: Beijing, China, 2008; pp. 49-52, 88, 265-267. (in Chinese)

30. NBSC (National Bureau of Statistics of China) China Statistical Yearbook 2009; China Statistics Press: Beijing, China, 2009; pp. 49-52, 91, 265-267. (in Chinese)

31. NBSC (National Bureau of Statistics of China) China Statistical Yearbook 2010; China Statistics Press: Beijing, China, 2010; pp. 50-53, 97, 291-293. (in Chinese)

32. NBSC (National Bureau of Statistics of China) China Statistical Yearbook 2011; China Statistics Press: Beijing, China, 2011; pp. 56, 95, 281-283. (in Chinese)

33. Deng, F.F.; Huang, Y.Q. Uneven land reform and urban sprawl in China: The case of Beijing. Prog. Plan. 2004, 61, 211-236.

34. Jeong, J.-H. From illegal migrant settlements to central business and residential districts: Restructuring of urban space in Beijing's migrant enclaves. Habitat Int. 2011, 35, 508-513.

35. Wang, Y.; Scott, S. Illegal farmland conversion in China's urban periphery: Local regime and national transitions. Urb. Geogr. 2008, 29, 327-347. 
36. Lin, G.C.S. Understanding Land Development Problems in Globalizing China. Eurasian Geogr. Econ. 2010, 51, 80-103.

37. Zhang, S.; Pearlman, K. Legislative support for urban land-use control in China. Environ. Plan. C-Govern. Policy 2009, 27, 399-412.

38. Xu, J.; Yeh, A.; Wu, F. Land Commodification: New Land Development and Politics in China since the Late 1990s. Int. J. Urb. Reg.Res. 2009, 33, 890-913.

39. Zhao, P.; Lue, B.; de Roo, G. Performance and dilemmas of urban containment strategies in the transformation context of Beijing. J. Environ. Plan. Manag. 2010, 53, 143-161.

40. Alterman, R. The Challenge of Farmland Preservation: Lessons from a Six-Nation Comparison. J. Am. Plan. Assoc. 1997, 63, 220-243.

41. Stobbe, T.E.; Eagle, A.J.; Cotteleer, G.; van Kooten, G.C. Farmland Preservation Verdicts-Rezoning Agricultural Land in British Columbia. Can. J. Agric. Econ.-Rev. Can. D Agroecon. 2011, 59, $555-572$.

42. Zhang, W.; Wang, W.; Li, X.; Ye, F. Economic development and farmland protection: An assessment of rewarded land conversion quotas trading in Zhejiang, China. Land Use Policy 2014, 38, 467-476.

43. Sokolow, A.D. Federal Policy for Preserving Farmland: The Farm and Ranch Lands Protection Program. Publ. J. Fed. 2010, 40, 235-256.

44. Zhong, T.; Mitchell, B.; Huang, X. Success or failure: Evaluating the implementation of China's National General Land Use Plan (1997-2010). Habitat Int. 2014, 44, 93-101.

45. Paik, W.; Lee, K. I Want To Be Expropriated!: The politics of xiaochanquanfang land development in suburban China. J. Contemp. China 2012, 21, 261-279.

46. Zhang, Q.; Wallace, J.; Deng, X.Z.; Seto, K.C. Central versus local states: Which matters more in affecting China's urban growth? Land Use Policy 2014, 38, 487-496.

47. Wong, K.K.; Zhao, X.B. The influence of bureaucratic behavior on land apportionment in China: The informal process. Environ. Plan. C-Govern. Policy 1999, 17, 113-126.

48. Su, F.B.; Tao, R.; Wang, H. State Fragmentation and Rights Contestation: Rural Land Development Rights in China. China World Econ. 2013, 21, 36-55.

49. SCNPC (Standing Committee of the National People's Congress). China Land Administration Law 1998. Available online: http://www.gov.cn/banshi/2005-05/26/content_989.htm (accessed on 21 April 2014). (in Chinese)

50. Whiting, S. Values in Land: Fiscal Pressures, Land Disputes and Justice Claims in Rural and Peri-urban China. Urb. Stud. 2011, 48, 569-587.

51. Deng, F.F. Public land leasing and the changing roles of local government in urban China. Ann. Reg. Sci. 2005, 39, 353-373.

52. Ding, C. Policy and praxis of land acquisition in China. Land Use Policy 2007, 24, 1-13.

53. Zhang, J.; Zhang, Y. Remote sensing research issues of the National Land Use Change Program of China. Isprs J. Photogramm. Remote Sens. 2007, 62, 461-472.

54. Editorial Department of China Land \& Resources Almanac (EDCLRA). China Land \& Resources Almanac 2000; Editorial Department of China Land \& Resources Almanac: Beijing, China, 2001; pp. 846-849. (in Chinese) 
55. MLR (Ministry of Land and Resources of China). China Land and Resources Statistical Yearbook 2010; Geological Pbulishing House: Beijing, China, 2011; pp. 200-228. (in Chinese)

56. NBSC (National Bureau of Statistics of China). China Statistical Yearbook 1998; China Statistics Press: Beijing, China, 1998; pp. 63-66, 107, 284-285. (in Chinese)

57. NBSC (National Bureau of Statistics of China). China Statistical Yearbook 1999; China Statistics Press: Beijing, China,1999; pp. 62-65, 113, 277-278. (in Chinese)

58. EDCLRA (Editorial Department of China Land \& Resources Almanac). China Land \& Resources Almanac 2000; Editorial Department of China Land \& Resources Almanac: Beijing, China, 2001; pp. 846-849. (in Chinese)

59. EDCLRA (Editorial Department of China Land \& Resources Almanac). China Land \& Resources Almanac 2001; Editorial Department of China Land \& Resources Almanac: Beijing, China, 2001; pp. 908-911. (in Chinese)

60. EDCLRA (Editorial Department of China Land \& Resources Almanac). China Land \& Resources Almanac 2002; Editorial Department of China Land \& Resources Almanac: Beijing, China, 2002; pp. 938-941. (in Chinese)

61. EDCLRA (Editorial Department of China Land \& Resources Almanac). China Land \& Resources Almanac 2003; Editorial Department of China Land \& Resources Almanac: Beijing, China, 2003; pp. 672-675. (in Chinese)

62. EDCLRA (Editorial Department of China Land \& Resources Almanac). China Land \& Resources Almanac 2004; Editorial Department of China Land \& Resources Almanac: Beijing, China, 2004; pp. 766-769. (in Chinese)

63. EDCLRA (Editorial Department of China Land \& Resources Almanac). China Land \& Resources Almanac 2005; Editorial Department of China Land \& Resources Almanac: Beijing, China, 2005; pp. 931-934. (in Chinese)

64. EDCLRA (Editorial Department of China Land \& Resources Almanac). China Land \& Resources Almanac 2006; Editorial Department of China Land \& Resources Almanac: Beijing, China, 2006; pp. 836-839. (in Chinese)

65. EDCLRA (Editorial Department of China Land \& Resources Almanac). China Land \& Resources Almanac 2007; Editorial Department of China Land \& Resources Almanac: Beijing, China, 2008; pp. 918-921. (in Chinese)

66. EDCLRA (Editorial Department of China Land \& Resources Almanac). China Land \& Resources Almanac 2008; Editorial Department of China Land \& Resources Almanac: Beijing, China, 2008; pp. 861-940. (in Chinese)

67. EDCLRA (Editorial Department of China Land \& Resources Almanac). China Land \& Resources Almanac 2009; Editorial Department of China Land \& Resources Almanac: Beijing, China, 2009; pp. 1128-1206. (in Chinese)

68. EDCLRA (Editorial Department of China Land \& Resources Almanac). China Land \& Resources Almanac 2010; Editorial Department of China Land \& Resources Almanac: Beijing, China, 2011; pp. 884-965. (in Chinese)

69. EDCLRA (Editorial Department of China Land \& Resources Almanac). China Land \& Resources Almanac 2011; Editorial Department of China Land \& Resources Almanac: Beijing, China, 2012; pp. 898-1003. (in Chinese) 
70. Office of State Land Inspector-general. Bulletin of State Land Inspector-general (No.1). Available online: http://www.gjtddc.gov.cn/ztzl/yw/kxfzg/sjcg/200806/t20080629_512014.htm (accessed on 21 April 2014). (in Chinese)

71. Office of State Land Inspector-general. Bulletin of State Land Inspector-general (No.2). Available online: http://www.mlr.gov.cn/sy/gd1/200904/t20090428_119115.htm (accessed on 21 April 2014). (in Chinese)

72. Office of State Land Inspector-general Bulletin of State Land Inspector-general (No.3). Available online: http://www.mlr.gov.cn/zwgk/zytz/201005/t20100501_147522.htm (accessed on 21 April 2014). (in Chinese)

73. Office of State Land Inspector-general. Bulletin of Supervisor of State Land (No. 4). Available online: http:/www.mlr.gov.cn/zwgk/zytz/201104/t20110419_843738.htm (accessed on 21 April 2014). (in Chinese)

74. Cohen, M. Empirical Research on the Deterrent Effect of Environmental Monitoring and Enforcement. Environ. Law Rep. 2000, 30, 10245-10252.

75. Gray, W.B.; Shadbegian, R.J. When and Why do Plants Comply? Paper Mills in the 1980s. Law Policy 2005, 27, 238-261.

76. Epple, D.; Visscher, M. Environmental Pollution: Modeling Occurrence, Detection, and Deterrence. J. Law Econ. 1984, 27, 29-60.

77. Liu, P.C. Regulator inspection and violation deterrence under Clean Water Act regulation of pulp and paper mill water pollution. Ph.D. Thesis, Stanford University, Stanford, CT, USA, 1995.

78. Polinsky, A.M.; Shavell, S. The economic theory of public enforcement of law. J. Econ. Lit. 2000, 38, 45-76.

79. Becker, G.S. Crime and Punishment: An Economic Approach. J. Political Econ. 1968, 76, 169-217.

80. Stigler, G.J. The Optimum Enforcement of Laws. J. Political Econ. 1970, 78, 526-536.

81. MLR (Ministry of Land and Resources of China). Circular on Inspection of Land Law Enforcement Based on Remote Sensing Technology. Available online: http:/www.chinabaike.com/ law/zy/bw/gw/gtb/1346364.html (accessed on 11 May 2014). (in Chinese)

82. Ho, S.P.S.; Lin, G.C.S. Non-agricultural land use in post-reform China. China Q. 2004, 179, $758-781$.

83. Koroso, N.H.; van der Molen, P.; Tuladhar, A.M.; Zevenbergen, J.A. Does the Chinese market for urban land use rights meet good governance principles? Land Use Policy 2013, 30, 417-426.

84. MLR (Ministry of Land and Resources of China). China Land \& Resources Almanac 2008; Editorial Department of China Land \& Resources Almanac: Beijing, China, 2009; pp. 869-871. (in Chinese)

85. Liu, F. A Discussion on the Relationship between Economic Growth and Land Illegal Use. Res. Sci. 2010, 32, 1558-1562. (in Chinese)

86. Long, K.; Chen, L. Analysis of Influencing Factors of Land Law Violations in China Based on Interprovincial Panel Data during the Period 1999-2008. Res. Sci. 2011, 33, 1171-1177. (in Chinese)

87. Liu, L.J.; Song, M.; Yokogawa, H.; Qu, B.X. Exploring the environmental Kuznets curve hypothesis between economic growth and farmland conversion in China. J. Fac. Agric. Kyushu Univ. 2008, 53, 321-327. 
88. Lopez, T.D.; Aide, T.M.; Thomlinson, J.R. Urban expansion and the loss of prime agricultural lands in Puerto Rico. AMBIO J. Hum. Environ. 2001, 30, 49-54.

89. Tan, R.; Beckmann, V.; van den Berg, L.; Qu, F. Governing farmland conversion: Comparing China with the Netherlands and Germany. Land Use Policy 2009, 26, 961-974.

90. Döös, B.R. Population growth and loss of arable land. Glob. Environ. Change 2002, 12, 303-311.

91. Wooldridge, J.M. Econometric Analysis of Cross Section and Panel Data; MIT Press: Cambridge, MA, USA, 2002; pp. 281-334.

92. Drukker, D.M. Testing for serial correlation in linear panel-data models. Stata J. 2003, 3, 168-177.

93. De Hoyos, R.E.; Sarafidis, V. Testing for cross-sectional dependence in panel-data models. Stata J. 2006, 6, 482-496.

94. Baum, C.F. XTTEST3: Stata Module to Compute Modified Wald Statistic for Groupwise Heteroskedasticity; S414801; Boston College Department of Economics: Chestnut Hill, MA, USA, 2000.

95. Hoechle, D. Robust standard errors for panel regressions with cross-sectional dependence. Stata J. 2007, 7, 281-312.

96. Cao, G.Z.; Feng, C.C.; Tao, R. Local "Land finance" in China's urban expansion: Challenges and solutions. China World Econ. 2008, 16, 19-30.

97. Tao, R.; Su, F.; Liu, M.; Cao, G. Land Leasing and Local Public Finance in China's Regional Development: Evidence from Prefecture-level Cities. Urb. Stud. 2010, 47, 2217-2236.

98. Ye, F.Z.; Wang, W. Determinants of Land Finance in China: A Study Based on Provincial-level Panel Data. Aust. J. Public Adm. 2013, 72, 293-303.

99. Deng, X.Z.; Huang, J.K.; Rozelle, S.; Uchida, E. Economic Growth and the Expansion of Urban Land in China. Urb. Stud. 2010, 47, 813-843.

100. Li, J. Land sale venue and economic growth path: Evidence from China's urban land market. Habitat Int. 2014, 41, 307-313.

101. Ding, C.R.; Lichtenberg, E. Land and Urban Economic Growth in China. J. Reg. Sci. 2011, 51, 299-317.

102. Liu, R.; Wong, T.C.; Liu, S. Peasants' counterplots against the state monopoly of the rural urbanization process: Urban villages and "small property housing" in Beijing, China. Environ. Plan. A 2012, 44, 1219-1240.

103. Choy, L.H.T.; Lai, Y.; Lok, W. Economic performance of industrial development on collective land in the urbanization process in China: Empirical evidence from Shenzhen. Habitat Int. 2013, 40, 184-193.

104. Song, W. Decoupling cultivated land loss by construction occupation from economic growth in Beijing. Habitat Int. 2014, 43, 198-205.

105. Tan, M.H.; Li, X.B. The changing settlements in rural areas under urban pressure in China: Patterns, driving forces and policy implications. Landsc. Urb. Plan. 2013, 120, 170-177.

106. Nelson, A.C. Preserving Prime Farmland in the Face of Urbanization-Lessons from Oregon. J. Am. Plan. Assoc. 1992, 58, 467-488.

107. Alterman, $\mathrm{R}$. The challenge of farmland preservation-Lessons from a six-nation comparison. J. Am. Plan. Assoc. 1997, 63, 220-243. 
108. Pierce, J.; Furuseth, O. Farmland protection planning in British Columbia. GeoJournal 1982, 6, $555-560$.

109. Yew, C.P. Explaining Land Use Change in a Guangdong County: The Supply Side of the Story. China Q. 2011, 27, 626-648.

110. Schmidt, E.E.; Thorne, J.H.; Huber, P.; Roth, N.; Thompson, E.; McCoy, M. A new method is used to evaluate the strategic value of Fresno County farmland. Calif. Agr. 2010, 64, 129-134.

111. Zhong, T.; Huang, X.; Zhang, X.; Scott, S.; Wang, K. The effects of basic arable land protection planning in Fuyang County, Zhejiang Province, China. Appl. Geogr. 2012, 35, 422-438.

112. Bai, X.; Shi, P.; Liu, Y. Society: Realizing China's urban dream. Nature 2014, 509, 158-160.

113. MS (Ministry of Supervision); MOHRSS (Ministry of Human Resources and Social Security); MLR (Ministry of Land and Resources of China). Regulations for Sanction on Violating Land Administration Decree. Available online: http://www.mlr.gov.cn/zwgk/zfgw/zfwj/200805/ t20080530_104722.htm (accessed on 15 May 2013). (in Chinese)

114. MLR(Ministry of Land and Resources of China). Notice of the Ministry of Land and Resources on Issuing the Case-filing Criteria for the Investigation and Handling of Land-related Violations 2005. Available online: http://www.mlr.gov.cn/zwgk/flfg/tdglflfg/200510/t20051020_640680.htm (accessed on 15 May 2013). (in Chinese)

115. MLR(Ministry of Land and Resources of China). Specifications for Land and Mineral Inspection Based on Satellite Image 2010. Available online: http:/www.mlr.gov.cn/zwgk/gfbz/201003/ t20100316_711437.htm (accessed on 15 May 2013). (in Chinese)

116. The General Office of State Council. Circular on the Establishment of State Land Supervision System 2006. Available online: http://www.gov.cn/zwhd/2006-07/24/content_393233.htm (accessed on 15 May 2013). (in Chinese)

117. Long, H.L.; Li, Y.R.; Liu, Y.S.; Woods, M.; Zou, J. Accelerated restructuring in rural China fueled by "increasing vs. decreasing balance" land-use policy for dealing with hollowed villages. Land Use Policy 2012, 29, 11-22.

118. Zhang, J. Interjurisdictional competition for FDI: The case of China's “development zone fever". Reg. Sci. Urban Econ. 2011, 41, 145-159.

119. Skinner, M.W.; Kuhn, R.G.; Joseph, A.E. Agricultural land protection in China: A case study of local governance in Zhejiang Province. Land Use Policy 2001, 18, 329-340.

120. Brown, G.P. Arable Land Loss in Rural China-Policy and Implementation in Jiangsu Province. Asian Surv. 1995, 35, 922-940.

(C) 2014 by the authors; licensee MDPI, Basel, Switzerland. This article is an open access article distributed under the terms and conditions of the Creative Commons Attribution license (http://creativecommons.org/licenses/by/3.0/). 